new treatment. (2) The patient has been much more careful over the carbohydrate ration as a result of the new treatment, and consequently requires less insulin.

\section{Travel in Italy}

Q. -What instructions should be given to a would-be traveller to Italy and Sicily this August, with special reference to (a) drinking tap-water, (b) inoculations, and (c) the possibility of contracting malaria?

A.- (a) Except in the largest towns the drinking of tap-water should be avoided unless it has been boiled previously. (b) It would be as well to be inoculated against typhoid and paratyphoid. (c) If the traveller is staying only in the larger towns there is little or no risk of his becoming infected with malaria. If he proposes to stay in small towns or villages or to be in the country in the evenings he should take proguanil $0.1 \mathrm{~g}$. daily during the time that he remains in the country.

\section{Anaesthetics for Domiciliary Midwifery}

Q.-In obstetrics in general practice open ether has the disadvantage of inflammability. To what extent is this a dangere.g., with open fires, paraffin lamps, etc.? If this is a real contraindication, what is the most satisfactory alternative anaesthetic for single-handed domiciliary obstetrics?

A.-The danger of using drop-ether in proximity to an open fire is that of burning rather than that of explosion of the ether vapour. Although it is generally stated in the textbooks that a mixture of ether vapour and air is explosive, experts in this field are doubtful whether this is so in ordinary clinical practice. The danger of fire, however, is very real, and is doubly dangerous because the ether vapour burns with an almost invisible flame which may travel some distance without any warning and so set fire to distant inflammable objects. The alternative to ether in domiciliary midwifery is either chloroform or trilene. In view of our pharmacological knowledge of these drugs, trilene seems to be the safer. Adequate analgesia with trilene is easily provided by means of one of the many types of apparatus on the market for the purpose. In one of these (i.e., the Cyprane inhaler) the concentration of trilene inhaled by the patient can be increased, should the anaesthetist desire it, and thus general anaesthesia may be induced. An alternative arrangement is to use any gas-oxygen apparatus and to put the trilene in the ether bottle which is usually to be found on such an apparatus. The strength of trilene vapour delivered from the Freedman inhaler is unlikely (except in patients with very low resistance) to produce general anaesthesia.

\section{Protecting a Stif Thumb}

Q.-A patient has had an injury which has resulted in ankylosis of the interphalangeal joint of his right thumb. He is a very keen cricketer, and finds now that, although he can hold his bat adequately, his right thumb is exposed to frequent injury while batting. He has asked me whether any metal protectors for fingers which have suffered injury are available, and I could not tell him. Can anything more be done for him?

A.-This is a problem which can probably best be solved by consultation between the patient and a skilled surgical appliance maker. Almost certainly some suitable protective covering for the thumb could be devised. It is possible that a thumbstall of relatively soft leather, with steel reinforcement sewn into it along the dorsum and over the tip of the thumb, would be adequate.

\section{Loss of Eyebrows}

Q.-What are the causes of loss of hair from the eyebrows? Is there any effective treatment? A male patient aged 29 has had patchy loss of hair from both eyebrows for the last two months. The patches are absolutely smooth and no broken hair can be seen; the skin in these areas is otherwise normal. There is no itching br soreness.

A.-This case is almost certainly one of alopecia areata, but the location of the changes makes it important to exclude local factors or irritation, such as infection in adjacent sinuses or teeth or errors of refraction. It is more probable that the affection is merely a reaction in a sensitive patient to some constitutional disturbance following minor infection or metabolic or emotional disturbance. In that event the assessment of the patient in relation to his environment may be important, and the prognosis will be influenced by the patient's past history and family history in relation to alopecia, dermatological affections, and mental health.

It must be remembered that the great majority of cases of alopecia areata are transient and of little significance and recover spontaneously. General treatment is important, and a holiday in new surroundings would probably be beneficial. Local measures are not indicated except perhaps to obscure the bald areas by means of an eyebrow pencil.

\section{NOTES AND COMMENTS}

Urticarial Reaction to Penicillin.-Lieutenant-Colonel $H . S$. ANDERSON, R.A.M.C. (ret.), writes: With reference to the question and answer under this heading ("Any Questions?" June 4, p. 1016) the questioner may be interested in a personal experience. In March, 1948 , I was given four injections of penicillin; the fourth one was given at my request. Nineteen days later urticaria appeared, was personally treated, and remained troublesome for about five weeks. In September, 1948, I received three injections of penicillin. Urticaria occurred on the thirteenth day, accompanied by strangury and haematuria. I was given an antihistamine drug by mouth for four days, but improvement was noticeable within 24 hours, and urine returned to normal rapidly.

Treatment of Asthma.-Major ERnest SOYsA (Colombo) writes : The association of asthma and leucocytosis in the case mentioned in "Any Questions ?" (April 23, p. 736) raises the interesting possibility of an eosinophilic reaction, even though this patient's previous allergic history may not be typical of the eosinophilic respiratory syndrome common in the Tropics. I have recently seen two similar cases. Both patients were Englishmen in whom leucocytosis had been detected a short time previously in London, neither having derived any lasting benefit from various asthma treatments. I had their differential counts done: one had 15,000 leucocytes per c.mm. with $48 \%$ eosinophils, and the other had 17,900 leucocytes with $50 \%$ eosinophils. Examination of the sputum of one patient by a special technique $^{1}$ revealed tyroglyphid mites. Oral medication with pentavalent arsenic (carbarsone 1 tablet b.d. for five days, repeated after an interval of two days) produced the typical dramatic cure in both patients, who showed the Herxheimer reaction reported previously in the Journal. ${ }^{2}$ A recent review' of a series of asthmatic cases (in Ceylon) with eosinophilia ranging from 1,000 to 50,000 cells per c.mm. disclosed occupational and environmental risks of inhaling airborne mites in $80 \%$ of the cases. Detection of mites in $62 \%$ of the sputum examinations undertaken was suggestive of pulmonary acariasis and confirmed the original findings ${ }^{1}$ that led to this line of inquiry. Three series of control cases subjected to identical sputum tests gave negative results. Pathognomonic appearances of the eosinophilic respiratory syndrome were observed in $50 \%$ of the pulmonary radiographs studied. The strikingly effective therapeutic action of organic arsenicals was constant. A few workers in other lands have confirmed observations made in Ceylon on the association of this eosinophilic respiratory syndrome with pulmonary acariasis. Further studies of the aetiology and pathology are necessary, and will doubtless be forthcoming, in view of the world-wide interest that appears to have been created in this remarkable malady.

\section{REFERENCES}

1 Carter, H. F., Wedd, G., and D'Abrera, V. St. E., Indian med. Gaz., 1944, 79, 163 2 Soysa, E., and Jayawardena, M. D. S., British Medical Journal, 1945, 1, 1 , 2 Soysa, E., and Jayawardena, M. D. S.,

Correction.-H. K. Lewis and Co. are not the publishers of Collected Papers: The Middlesex Hospital Medical School (June 18, p. 1085).

All communications with regard to editorial business should be addressed to THE EDITOR, BRITISH MEDICAL JOURNAL, B.M.A. HOUSE, TAVISTOCK SQUARE, LONDON, W.C.1. TELEPHONE: EUSTON 2111. TELEGRAMS: Aitiology. Westcent, London. ORIGINAL ARTICLES AND LETTERS forwarded for publication are understood to be offered to the British Medical Journal alone unless the contrary be stated.

Authors desiring REPRINTS should communicate with the Publishing Manager B.M.A. House, Tavistock Square, W.C.1, on receipt of proofs. Authors overseas should indicate on MSS. if reprints are required, as proofs are not sent abroad.

ADVERTISEMENTS should be addressed to the Advertisement Manager B.M.A. House. Tavistock Square. London, W.C.1 (hours 9 a.m. to 5 p.m.) TElEPHONE: EUSTON 2111. TElegrams: Britmedads, Westcent London. MEMBERS' SUBSCRIPTIONS should be sent to the SECRETARY of the Association. TELEPHONE: EUSTON 2111. TElegrams: Medisecra, Westcent London.

B.M.A. SCOTrish OFfice: 7, Drumsheugh Gardens, Edinburgh 